\title{
Implementasi Manajemen Sumber Daya Manusia dalam Meningkatkan Kualitas Pengelolaan Zakat
}

\author{
Usep Saepul Alam ${ }^{1 *}$, Dindin Solahudin ${ }^{1}$, Yuliani ${ }^{2}$ \\ ${ }^{2} J u r u s a n$ Pengembangan Masyarakat Islam, Fakultas Dakwah dan Komunikasi, UIN Sunan \\ Gunung Djati, Bandung \\ 13Jurusan Manajemen Dakwah, Fakultas Dakwah dan Komunikasi, UIN Sunan Gunung Djati, \\ Bandung \\ *Email: alghofun031296@gmail.com
}

\begin{abstract}
ABSTRAK
Penelitian ini bertujuan untuk mengetahui pengelolaan zakat yang ada di lembaga Pusat Zakat Umat melalui beberapa tahapan proses perencanaan, pengorganisasian, aktualisasi dan pengawasan terhadap sumber daya manusia yang ada di lembaga Pusat Zakat Umat sehingga dapat berjalan dengan efektif dan efesien terhadap pengelolaan zakat. Penelitian ini menggunakan metode deskriptif dengan melakukan pendekatan secara kualitatif, Sehingga hasil dalam penelitian ini diperoleh data pengelolaan zakat yang mencakup beberapa susunan program yang ada di lembaga Pusat Zakat Umat. Ada beberapa tahapan proses implementasi sumber daya manusia dalam pengelolaan zakat di Pusat Zakat Umat, yaitu; Pertama, perencanaan program yang akan dicapai pada tahun berikutnya. Kedua, pengorganisasian yang melibatkan seluruh amil dalam kepengurusan organisasi. Ketiga, melakukan bmbingan kepada para amil untuk meningkatkan semangat kerja, berupa motivasi-motivasi yang bisa menggugah semangat. Keempat, pengawasan langsung dan tidak langsung kepada para amil untuk melihat hasil dari kerja yang dilakukan selama beberapa bulan kebalakang.

Kata Kunci : Pengelolaan Zakat; lembaga; Sumber Daya Manusia.
\end{abstract}

\begin{abstract}
Several stages of the process of conducting studies in advance including namely planning, organizing, actualizing and controlling buman resources at the Zakat Center institution. The people so that it can run effectively and efficiently towards the management of zakat. The method used in this research is to use a descriptive method with a qualitative approach, so that the results in this study are obtained at the Central Zakat Institution obtained from zakat management data which includes a number of existing program structures at the Zakat Center Institution. There are several stages carried out in implementing Human Resources in the management of zakat, the first of which is program planning that will be achieved the following year. The second is organizing by involving all amil in the management of the organization so
\end{abstract}


Usep Saepul Alam, D, Yuliani.

that it can easily be divided into tasks in managing zakat. Third is the implementation by applying some ideas to amil with the aim to increase morale including motivations that can inspire the spirit of amil. The fourth is supervision conducted and indirectly to the amil to see the results of the work done over the past few months.

Keywords: Management of Zakat; institution; Human Resources.

\section{PENDAHULUAN}

Pusat Zakat Umat merupakan lembaga amil zakat nasional yang ada di bawah naungan pemerintahan, lembaga pusat zakat umat mempunyai hal yang sangat unik dalam beberapa hal yang membuat penulis ingin meneliti pusat zakat umat untuk dijadikan bahan referensi dalam jurnal penulis. Sehingga dalam beberapa kurun waktu seiring berjalannya waktu penulis menemukan beberapa hal yang memang harus penulis teliti, yaitu dalam recruitment yang dilakukan oleh lembaga menggunakan satu hal yang berbeda dengan yang lain yaitu melalui relawan yang sudah menjadi bagian lembaga pusat zakat umat dalam segi hal kemampuan berkomunikasi dan juga kemampuan dalam mengayomi masyarakat yang ada di luar negeri maupun di dalam negeri.

Dalam menjalankan sebuah program harus adanya perencanaan yang matang agar dapat mecapai tujuan yang sudah direncanakan, di antaranya beberapa tahap harus dilewati sebelum sampai kepada tujuan yang baik yaitu dengan adanya implementasi sumber daya manusia terhadap lembaga, sehingga dapat didefinisikan bahwa Implementasi merupakan sebuah penerapan rencana yang telah diatur sedemikian rupa oleh suatu lembaga demi mencapai suatu tujuan tertentu, dengan melaksanakan sesuai dengan koridor yang telah tertera dalam tata tertib, sehingga dalam pelaksanaan yang akan dilakukan oleh lembaga tersebut tertata rapi dan mempunyai latar belakang yang bisa memungkinkan tujuan itu dapat tercapai dengan baik dan benar. Tidak hanya itu dalam penerapan ini sebuah lembaga harus mempunyai tujuan yang mempunyai kejelasan dalam melaksanakannya, tidak hanya melaksanakan sebuah kegiatan tetapi harus mempunyai sasaran tertentu yang nantinya akan dicapai secara sistematis sesuai dengan ketentuan yang di buat.

Zakat merupakan sesuatu kewajiban yang harus dilakukan oleh setiap muslim dan muslimat guna melengkapi ibadah yang telah diperintahkan oleh Allah SWT kepada umat Nabi Muhammad Saw. di antaranya salah satu rukun Islam yang 5, zakat di bagi menjadi dua bagian untuk ditunaikan, ada zakat yang harus dikeluarkan sesuai waktu yang telah ditentukan oleh syariat Islam ada juga zakat yang dikeluarkan ketika sudah mencapai nisab seseorang yaitu zakat fitrah dan zakat mal. Zakat fitrah ini merupakan zakat yang dikeluarkan oleh setiap umat muslim untuk menyempurnakan puasa wajib pada bulan Ramdhan yang bertepatan sebelum shalat idul fitri dilaksanakan oleh seluruh umat islam, adapun zakat mal merupakan zakat yang dikeluarkan oleh sebagian orang di antaranya 
mempunyai harta lebih sudah mencapai nisab sehingga wajib untuk orang tersebut mengeluarkan zakat yang telah ditentukan oleh syariat islam.

Tapi ada beberapa ikhtilaf yang menjadikan orang-orang yang belum faham seberapa besar mencapai nisab untuk mengeluarkan zakat, sehingga mereka malas untuk mengeluarkan zakat karena ketidaktauan mereka, maka oleh sebab itu diharuskannya untuk memahami bagaimana syariat Islam yang sebenarnya untuk dilaksanakan agar tidak menyimpang kepada jalan yang tidak sesuai dengan syariat Islam.

Menurut Undang-Undang No. 23 tahun 2011 tentang pengelolaan Bab ke 1 pasal 1 bahwa zakat merupakan harta yang wajib dikeluarkan oleh seorang muslim atau badan usaha untuk diberikan kepada yang berhak menerimanya sesuai dengan syariat islam, selain itu berdasarkan Undang-Undang Nomor 38 Tahun 1999 tentang perlu di ganti, sehingga perubahan itu menimbulkan beberapa kegiatan pengelolaan zakat dinilai sudah tidak sesuai dengan perkembangan kebutuhan masyarakat sehingga meliputi perencanaan, pengumpulan, pendistribusian dan pendayagunaan.

Menurut Undang-undang No. 38 tahun 1999 tentang pengelolaan zakat adalah mengoptimalkan pendistribusian zakat yang bertujuan untuk pemerataan ekonomi dan pembangunan, yang ditopang dengan suatu Badan Pengelola Zakat yang modern dan profesional. Zakat dengan segala posisi, fungsi dan potensi yang terkandung di dalamnya dapat berperan secara positif-progressif dalam gerakan ekonomi kerakyatan. Di dalamnya terdapat unsur kesejahteraan bersama, seperti yang tercantum dalam pasal 33, 27 ayat (2) dan pasal 34 UUD 1945. Bahkan secara lebih luas, dana zakat dapat didistribusikan bagi sektor permodalan tanpa bunga dalam berbagai usaha-usaha ekonomi produktif. Dana zakat harus diarahkan kepada usaha-usaha kecil yang dikelola oleh mayoritas ummat, dalam hal ini adalah bidang pertanian, dan mata pencaharian mayoritas ummat Islam dan rakyat Indonesia.

Salah satu ajaran Islam yang mempunyai nilai sosial yaitu zakat. Zakat merupakan kewajiban yang disyariatkan oleh Allah SWT kepada umat manusia khususnya Islam, ibadah yang merupakan salah ibadah setara dengan shalat, puasa, dan munggah haji ke Baitullah. Akan tetapi zakat ini bukanlah ibadah yang dilaksanakan dengan fisik yakni ibadah amaliah, ibadah yang mengeluarkan harta kekayaan yang mempunyai tujuan untuk membantu orang-orang miskin untuk bisa bangkit keterpurukan mereka. Oleh karena itu, dalam membina dan mengayomi masyarakat yang baik, maka harus adanya pengelolan yang baik sesuai dengan ketentuan yang ada.

Kata dasar dari pengelolaan menurut Suhartsimi Arikunto (1993: 31), adalah dapat disamakan dengan kata manajemen yang berarti pula dapat di artikan sebagai pengaturan pengurusan, sehingga banyak orang yang mengartikan bahwa pengelolaan itu adalah manajemen sebagai pengadministrasian, 
Usep Saepul Alam, D, Yuliani.

pengaturan dan memang pengertian itu sudah banyak diketahui oleh benyak orang terutama oleh kalangan para ilmuan dan pelajaran, baik itu di bangku sekolah maupun di bangku perkuliahan. Dengan kata lain pengelolaan dapat di artikan sebagai usaha atau pekerjaan yang dilakukan oleh beberapa atau sekelompok orang untuk melakukan suatu rangakaian pekerjaan dalam bergerak mencapai tujuan yang telah ditentukan.

Pengelolaan yang dilakukan oleh lembaga baik itu lembaga yang sifatnya individual maupun yang sifatnya masih membutuhkan klien yang lain sehingga dalam pengelolaan itu sendiri terdapat beberapa fungsi yang harus dipahami agar dalam menjalankan suatu rencana dapat dikelola dengan baik dan hasilnya pun akan lebih maksimal, Sehingga memberikan out-put yang jelas terhadap organisasi dan lembaga tersebut. Fungsi pengelolaan itu tidak jauh berbeda dengan fungsi manajemen karena pengertian fungsi pengelolaan dan fungsi manajemen itu sendiri yaitu diantaranya: perencanaa (Planning), pengeoragniasian (organizing), pengarahan (directing). Yang akan mengacu kepada tiga fungsi ini dalam melakukan suatu kegiatan dalam sebuah organisasi (Irawan,1997: 5).

Manajemen pengelolaan itu bisa dipungkiri sangat penting untuk dijadikan sebuah landasan yang bagus untuk kedepannya. tapi dengan itu juga dalam pengelolaan manajemen lembaga harus mempunyai gol atau target yang harus dicapai dalam kian waktu beberapa tahun kedeapannya. A.F. Stoner mengemukakan pendapatnya bahwa manajemen sumber daya manusia merupakan sebuah proses yang dilakukan oleh suatu lembaga untuk memenuhi kebutuhan organisasi atau perusahaan dengan menempatkan orang-orang yang berkompeten di bidangnya yang akan mengisi jabatan atau kursi yang telah ditetapkan oleh perusahaan (Yani, 2011: 3). Dalam hakikat dan tantangan, ada personal manajemen dan ada juga manajemen sumber daya manusia yang timbul pada tahun yang berbeda di antaranya tahun 1960-an dan tahun 1940-an, antara manajemen sumber daya manusia dan personal manajemen mempunyai cakupan runag lingkup yang berbeda antara tingkatannya.

\section{LANDASAN TEORITIS}

Dalam penelitian ini peneliti kemukakan landasan teori yang terjadi dalam skripsi penulis yaitu tentang Manajemen Sumber Daya Manusia dalam Pengelolaan Zakat, pengelolaan pada dasarnya menurut Irawan (1997: 5) adalah pengendalian dan pemanfaatan semua sumber daya manusia yang memerlukan suatu perencanaan yang diperlukan untuk penyelesaian suatu tujuan kerja tertentu dengan sebaik mungkin. Pengelolaan juga sama halnya dengan pengertian manajemen yaitu penggerakan, pengoragnisasian dan pengarahan usaha manusia untuk memanfaatkan usahanya secra efektif material dan fasilitas untuk mencapai suatu tujuan tertentu. G.R. Terry berpendapat tentang pengelolaan merupakan sebuah proses khusus yang terdapat dalam kegiatan perencanaan, 
pengorganisasian, pengarahan, dan pengawasan yang dilaksanakan untuk menentukan dan menggapai target yang harus dicapai dalam kurun waktu beberapa tahun kedepan dalam pendayagunaan sumber daya manusia dan sumber lainya (Hasibuan, 2011: 3). Sedangkan manajemen dikemukakan Mary Parker Follet dalam buku Pengantar Manajemen adalah seni melalui orang lain dalam menyelesaikan sesuatu (Hasibuan, 2005: 5).

Selanjutnya Reksopoetranto (1992) berpendapat bahwa pengelolaan (manajemen) sebagai berikut: (1) Manajemen atau pengelolaan adalah unsur yang bertugas dalam mengendalikan beberapa sumber dan dan sumber daya manusia agar yang di dimiliki organisai dapat dimanfaatkan daya guna dan berhasil dengan mencapai suatu tujuan. (2) Manajemen merupakan seni atau ilmu perencanaan, pengorganisasian pengarahan, pengkoordinasian dan pengkontrolan manusia dan sumber daya manusia dalam melakukan suatu tujuan tertentu. (3) Manajemen merupakan dirumuskan untuk menyelasikan suatu pekerjaan usaha orang lain (Safitri, 2019: 5).

Kata dasar dari pengelolaan adalah dapat disamakan dengan kata manajemen yang berarti pula dapat diartikan sebagai pengaturan pengurusan, sehingga banyak orang yang mengartikan bahwa pengelolaan itu adalah manajemen sebagai pengadministrasian, pengaturan dan memang pengertian itu sudah banyak diketahui oleh benyak orang teruratam oleh kalangan para ilmuan dan pelajaran, baik itu di bangku sekolah maupundi bangku perkuliahan (Arikunto, 1993: 31). Dengan kata lain pengelolaan dapat diartikan sebagai usaha atau pekerjaan yang dilakukan oleh beberapa atau sekelompok orang untuk melakukan suatu rangakaian pekerjaan dalam bergerak mencapai tujuan yang telah ditentukan.

Kenapa dikatakan manajemen? Karena pengelolaan itu merupakan bagian dari perencanaan, pengeorganisasian, pengambilan keputusan dan pengendalian terhadap organisasi manusia, dan berdasarkan definisi manajemen yang telah dijelaskan bahwa secara garis besar tahap-tahap yang harus dilakukan oleh manajemen yaitu dengan melakukan manajemen meliputi diantaranya perencanaan, pengorganisasian, pelaksanaan dan pengawasan. Sehingga perencanaan merupakan suatu proses yang pada dasarnya ada pada suatu kegiatan pengelolaan. Juga merupakan syarat yang mutlak untuk dilakukan untuk kegiatan pengelolaan berikutnya. Kemudian dalam pegelolaan ada yang disebut dengan pengorganisasian yang berkaitan dengan pelaksanaan perencaan awal yang telah ditentukan, sehingga harus adanya controling atau pengawasan terhadap organisasi yang telah direncanakan dan diorganisasikan.

Oleh karena itulah menurut Manullang (2000: 13) di dalam bukunya berpendapat bahwa manajemen personalia merupakan bagian dari manajemen, karena bagaimanapun juga ketika seseorang berbicara soal manajemen maka mau tak mau akan menyinggung soal pegawai, karyawan atau bisa disebut manusia 
Usep Saepul Alam, D, Yuliani.

pada umumnya. Maka dapat disimpulkan bahwa manajemen personalia itu adalah ilmu dan seni untuk memperoleh, memajukan sebuah instantsi atau organisasi untuk mecapai suatu tujuan tertentu yang direalisir daya gunanya dan sekalius membangkitkan kembali gairah bekerja para pegawai atau karyawan.

Sedangkan menurut T. Hani Handoko (2012: 56) mendefinisikan bahwa manajemen sumber daya manusia merupakan sebuah proses perencanaan, pengorganisasian, pengarahan dan pengawasan kegiatan-kegiatan pengadaan, pengembangan pemberian kompensasi pengintegrasian, dan pemeliharaan sehingga pelepasan sumber daya manusia agar tercapai berbagai tujuan yang telah ditentukan, baik individu, organisasi maupun masyarakat. Adanya definisi manajemen personalia menurut Gary Dessler yakni "personel management is the concept and techniques one need to carry out the.'the people' or personel aspect of a management position, including recruitment, scereening, training, rewarding and appraising".

Manajemen personal adalah konsep dan teknik yang harus dilakukan seseorang. Aspek orang atau personal dari posisi manajemen, termasuk rekrutmen, scereening, pelatihan, penghargaan dan penilaian". Manajemen sumber daya manusia merupakan masalah-masalah yang berkesinambungan dengan penggunaan, pembinaan dan perlindungan sumber daya manusia baik itu yang berada di dalam perusahaan maupun di luar perusahaan.

Sedangkan menurut Basir Barthos (2012: 1), yang dimaksud dengan personal manajemen merupakan sumber daya manusia yang langsung berada di dalam perusahaan atau organisasi terutama perusahaan modern yang dikenal banyak terutama dengan sektor formal.

Menurut Flippo bahwa manajemen personalia merupakan pengorganisasi, perencanaan, pengawasan, pengarahan, penempatan, pemeliharan dan pelepasan sumber daya manusia dalam pencapaian sebagai individu organisasi dan masyarakat (Setiawan, 2017: 7). Sedangkan menurut Frech bahwa manajemen personalia adalah sebagai seleksi, penarikan, penggunaan, pengembangan dan pendayagunaan sumber daya manusia dalam mencapai tujuan tertentu.

Sekali lagi, menurut Hani Handoko (2012: 56), dapat didefinisikan bahwa manajemen personalia atau manajemen sumber daya manusia adalah langkah utamanya yaitu mengelola manusia dan sangat diperlukan oleh organisasi dengan tujuan untuk memberikan kontribusi lebih dan kerja yang efektif dan produktif. Manajemen perosonalia akan menunjukkan bahwa sangat di perlukannya sebuah perusahaan untuk mendapatkan dari suatu pekerjaan yaitu mengembangkan, menggunakan, memelihara karwayan yang berkualitas dan berkuantitas, yang terakhir harus adanya evaluasi di batas akhir yang telah ditentukan oleh perusahaan.

Salah satu yang menjadi masalah selama ini antara lain adalah masalah pengelolaan zakat yang belum dilakukan secara professional sehingga pengumpulan dan penyaluran zakat menjadi kurang terarah (Amymie, 2017: 3). 
Padahal sejatinya bila dana zakat dapat dikelola secara maksimal dana tersebut dapat mendorong program pembangunan berkelanjutan atau yang biasa disebut Sustainable Development Goals (SDGs), yang sekarang program tersebut menjadi program baru Pemimpin 193 Negara, PBB, Bank Dunia dan organisasiorganisasi nirlaba di UN Summit New York yakni tentang Tujuan Pembangunan Berkelanjutan yang di sebut sebagai Agenda 2030, meneruskan agenda Milenium Development Goals (MDGs) yang telah berakhir pada Desember 2015. Lembaga sosial atau organisasi sosial merupakan susunan kerja suatu masyarakat, atau proses penyusunan suatu tindakan dan hubungannya dengan tujuan sosial yang diterima umum. Proses penyusunan tersebut memperhitungkan setiap penyesuaian masyarakat melalui kebebasan memilih. Pilihan serta keputusan penting untuk mewujudkan suatu masyarakat, dan menentukan relasi antar kelompok (Sobur, 2014 : 571).

\section{HASIL DAN PEMBAHASAN}

Berdasarkan wawancara yang dilakukan pada tanggal 19 juni bersama Direktur Eksekutif LAZ Persatuan Islam Angga Nugraha diperoleh data bahwa Pusat zakat Umat (LAZ Persatuan Islam) adalah sebuah lembaga pengelolaan zakat, infaq dan Shadaqah (ZIS) yang berkhidmat untuk meningkatkan kesejahtraan umat dalam bidang pendidikan, dakwah, sosial, kesehatan dan juga ekonomi (Yani, 2011: 3).

Pusat zakat umat didirikan berdasarkan SK Menteri Agama RI no. 552 Tahun 2001 dan SK Kementerian Agama RI No. 865 Tahun 2016 serta didukung oleh tenaga amil zakat professional. Pusat zakat umat mencenangkan visi sebagai lembaga yang menglola dana zakat, infaq, dan shadaqah (ZIS) secara amanah, professional, dan trasparan untuk disalurkan bagi kesejahteraan umat di berbagai wilayah Indonesia.

Perjalanan sejarahnya, PZU sebagai organisasi pengelola zakat sejak waktu dibentuknya sudah berkiprah dan mengabdi untuk kepentingan umat. PZU sebagai institusi sosial yang keberadaannya memberi nilai manfaat bagi umat, tentu saja masih tetap bertahan sampai sekarang dan masih tetap ditumbuhkembangkan serta turut mendeterminasi dalam menjaga dan menyelamatkan umat baik dalam bidang ibadah maupun sosial.

Visi lembaga Pusat Zakat Umat adalah menjadi lembaga yang unggul dan kompetitif dalam pemberdayaan umat sedangkan misinya adalah (1) Membentuk citra lembaga yang amanah dan transparan. (2) Membangun kesadaran umat untuk membayar ZIS ke lembaga. (3) Melaksanakan pelayanan prima (service excellent) kepada mustahiq, Muzakki, Munfiq dan Mutashadiq. (4) Meningkatkan kualitas dan kapsitas amil yang amanah dan profesional. (5) Mengoptimalkan potensi ZIS melalui penghimpunan yang berorientasi pada pengembangan pemberdayaan produktivitas pendidikan, dakwah, social dan ekonomi. (6) 
Usep Saepul Alam, D, Yuliani.

Menciptakan program pemberdayaan yang inovtaif dan solutif.

\section{Proses Rekruitmen dan Penempatan Sumber Daya Manusia Lembaga Pusat Zakat Umat Sumur Bandung}

\section{Rekruitmen}

Menurut narasumber Angga Nugraha, Manager Eksekutif (17/06/2018) memaparkan bahwa lembaga pusat zakat umat melakukan precrutan pegawai atau amil zakat yang layak untuk ditempatkan diberbagai posisi dengan melakukan beberapa proses dari mulai mengikut sertakan para calon amil diberbagai event atau acara yang diselenggarakan pusat zakat umat dengan menentukan proses awal yaitu dari mulai mengisi pendaftaran yang dibuat dari dari google form untuk diisi sesuai data masing- masing, setiap relawan yang ingin masuk menjadi bagian pusat zakat umat wajib mengikuti training yang dilaksanakan sesuai tanggal yang telah ditentukan setelah itu peserta melakukan sesi wawancara yang akan dipimpin oleh beberapa karyawan yang sudah senior untuk memberikan pertanyaan-pertanyaan yang bisa membantu peserta bisa masuk kepada bagian pusat zakat umat (Harsuko Riniwati, 2016: 163).

Strategi yang dilakukan oleh lembaga PZU itu sangatlah sulit untuk dilakukan karena dengan menemukan relawan yang akan masuk kepada lingkup lembaga pusat zakat umat harus adanya beberapa tahapan demi tahapan guna mengetahui sejauh mana relawan yang datang untuk mendaftar mengetahui fungsi dan manfaat zakat itu sendiri serta mengetahui beberapa elemen yang ada di lembaga pusat zakat umat, oleh karena itu dengan melakukan seleksi dan sebagainya maka akan ditemukan siapa yang memenuhi syarat dalam ketentuan menjadi relawan sehingga di masa yang akan datang dapat di promosikan menjadi amil zakat sesuai dengan kemampuan yang dimiliki oleh individu masing-masing.

Salam melakukan strategi recruitment, itu harus adanya beberapa cara yang baik sehingga tidak akan adanya kegagalan yang patal ketika ada hasil yang ditemukan tidak sesuai dengan persyaratan yang telah di tentukan dari awal untuk memenuhi kebutuhan yang menjadi kekurangan di lembaga pusat zakat umat, relawan merupakan bagian dari kebutuhan yang di perlukan pusat zakat umat untuk menjadi kader di masa yang akan datang, sehingga tidak sembarangan dalam melakukan recrutment karena itu hubungannya dengan kader yang akan mengelola dana zakat, infaq dan shadaqah (Elbadiansyah, 2019: 56).

Beliau mengatakan bahwa yang masuk sebagai relawan tidak ada batasan baik itu dari persis maupun dari mana saja yang terpenting hal yang harus diketahui yaitu relawan yang masuk itu sesuai dengan keinginan dan menjadi hal yang dibutuhkan oleh lembaga pusat zakat umat. Jadi kemampuan itu paling depan yang dibutuhkan oleh lembaga bukan pemahaman tentang ormas yang 
harus di tonjolkan, oleh sebab itu lembaga amil zakat nasional khususnya pusat zakat umat yaitu keahlian yang menjadi hal paling penting karena itu membutuhkan pemahaman yang baik dalam jangka yang panjang demi menghasilkan dan peningkatan di setiap tahunnya.

Oleh sebab itu pusat zakat membutuhkan orang yang mampu dalam bekerja lebih rajin, disiplin, dan juga mampu menyelesaikan berbagai masalah yang akan menjadi hambatan bagi lembaga pusat zakat serta menjadi amil yang mampu memberikan yang terbaik kepada lembaga dan mempunyai tanggung jawab yang tiinggi dalam menyelesaikan semua pekerjaan yang sudah menjadi tangung jawabnya.

\section{Penempatan}

Menurut Angga Nugraha (17/06/2019) dalam proses penempatan SDM bahwa dalam penempatan relawan itu ditempatkan oleh lembaga bukan keinginan sendiri relawan tersebut dengan susunan tertentu yang diinginkan oleh lembaga. Tetapi, ketika relawan tersebut sudah menjadi pilihan lembaga pusat zakat umat untuk dipromosikan kepada yang lebih tinggi lagi yaitu sebagai amil maka relawan yang sudah terpilih bisa mempelajari beberapa posisi sesuai dengan kemampuan dasar yang dimiliki oleh relawan tersebut.

Perusahaan menyadari bahwa Sumber Daya Manusia merupakan modal dasar untuk melakukan pembangunan dan pemberdyaaan. Oleh karena itu, ada beberapa tahapan yang harus dilewati oleh amil zakat untuk dapat masuk mejadi bagian dari pusat zakat umat dalam pendayagunaan yang akan dilakukan disana, oleh karena itu dengan adanya proses tersebut pusat zakat umat bisa melihat sejauh mana pengetahuan tentang jobdes yang akan ditekuninya sehingga dengan itu dapat menjadu bagian pusat zakat umat sesuai dengan yang dibutuhkan oleh lembaga (Elbadiansyah, 2019: 70).

Posisi yang sudah disiapkan itu menjadi tujuan utama untuk para relawan katika sudah lulus di tahap yang sudah dilewati dari mulai seleksi tulis, wawancara dan lain sebagainya, sehinga dengan adanya ujian-ujian yang dilakukan akan membuat para calon amil zakat pusat zakat umat menjadi lebih mengetahui alur kinerja yang harus dilakukan untuk senantiasa membangun dan meningkatkan lembaga pusat zakat umat menjadi lebih baik lagi. Juga dapat memenuhi target yang sudah direncanakan dari awal.

Relawan wajib mengetahui Job deskripsinya masing-masing untuk terus di pelajari kembali bagaimana cara kerja serta memahami proses kerja yang baik dan benar, agar dengan kinaerja yang disediakan oleh amil tidak menjadi hambatan untuk terkumpulnya dana zakat, infaq dan shadaqah tetapi meningkat dan berkembang seiring waktu yang berjalan. Sehinga dengan itu lembaga akan menilai sejauh mana pekerjaan yang dilakukan oleh amil yang baru memasuki lembaga pusat zakat umat untuk dijadikan karyawan tetap untuk pendayagunaan dana zakat, infaq dan shadaqah. 
Usep Saepul Alam, D, Yuliani.

Menyeleksi karyawan dengan hati-hati belum bisa menjamin bahwa karyawan tersebut bekerja dengan efektif, bahkan berpotensi dapat melakukan pekerjaannya. karena hal tersebut ketidaktahuan karyawan baru mengenai apa yang harus dilakukan dan bagaiana melakukannya (Saihudin, 2019: 17). Kemampuan yang dimiliki oleh individu bisa disesuaikan dengan keadaan posisi yang sudah disediakan oleh lembaga, serta dapat berlajar pada hal yang lain ketika perkejaan yang sudah menajdi pilihan itu sudah dapat dipahami dengan benar. Mengetahui ilmu lain selain dari apa yang sedang ditekuni itu sangatlah diperbolehkan, guna untuk menambah wawasan pemikiran dan skill yang dimiliki oleh individu masing-masing yang sudah menjadi pekerjaan setiap harinya.

Strategi yang harus dilakukan oleh lembaga sehingga dapat memancing seluruh karyawan mau bekerja dengan memenuhi target pencapaian. Oleh karena itu, sesuai dengan kebutuhan yang diinginkan dan yang diinginkan oleh lembaga itu tidak akan sama, maka dengan mempelajari hal yang baru itu menjadi wawasan yang baru untuk menjadi harga jual bagi individu yang mau mengerjakan sesuatu diluar kemampuan orang lain yang tidak bisa dilakukan. Maka kebutuhan itulah yang harus disesuaikan dengan kebutuhan yang diinginkan oleh lembaga pusat zakat umat khusunya.

Kesejahteraan sosial sendiri dalam artian yang sangat luas, mencakup dalam berbagai tindakan yang dilakukan oleh individu ataupun organisasi untuk mencapai taraf hidup yang lebih baik. Dalam hal ini, kesejahteraan sosial berkaitan dengan organisasi atau institusi pelayanan. Artinya, dengan adanya lembaga atau institusi yang ada dimasyarakat dapat menciptakan atau meningkatkan kesejahteraan sosial melalui pelayananan-pelayananan yang diberikan oleh institusi atau lembaga tersebut. Pelayanan inilah yang nantinya dapat memaksimalkan akses masyarakat dalam meningkatkan kesejahteraan hidup mereka.

Berdasarkan data di atas, kita dapat melihat bahwa dalam penyelenggaraan pendayagunaan zakat dibutuhkan persiapan yang matang dan pelaksanaan yang optimal pula. Maka dari itu, penulis tertarik untuk meneliti tentang Pendistribusian dan Pendayagunaan Zakat dalam Pencapaian Sustainable Development Goals.

\section{Pembinaan dan Pelatihan Sumber Daya Manusia Lembaga Pusat Zakat Umat Sumur Bandung}

\section{Pembinaan}

Dalam pembinaan yang dilakukan oleh lembaga pusat zakat umat menurut narasumber yang penulis wawancarai yaitu Angga Nugraha sebagai Manager Eksekutif, bahwa pembinaannya meliputi beberapa aspek yang selalu ditekankan kepada seluruh SDM amil zakat pusat zakat umat diantaranya: Kesatu, 
diberikannya motivasi kepada karyawan agar dapat lebih meningkatkan kembali kinerja yang selama menjalani dan mengembangakan pendayagunaan dana zakat, infaq dan shadaqah. Sehingga dengan adanya motivasi yang diberikan oleh manager khususnya kepada para amil yang setiap harinya bergelut dengan beberapa pekerjaan dan ditutut untuk konsisten dalam bekerja yaitu dengan memberikan berlibur bareng ketika massa libur yang akan datang, selain itu disetiap harinya para atasan terus memberikan semangat kepada karyawan yang hari-harinya ada yang lagi Badmood atau kurang semangat dalam bekerja agar dalam menjalankan program yang telah dirancang sedemikian rupa bisa di leanding sesuai dengan ketentuan yang telah disusun.

Kedua, selain diberikan pembinaan secara rutin ada juga pembinaan yang diberikan oleh PP. Persatuan Islam tentang mental dan sosial di setiap bulannya. Tujuan dari pembinaan tersebut manfaatnya untuk memberikan pengarahan kepada amil dalam melayani warga yang sedang diberikan ujian oleh Allah baik itu bencana banjir, longsor, tsunami, gempa bumi, dan juga bencana lainnya yang sekali waktu itu akan terjadi dimana saja. Jadi pembinaan yang diberikan kepada amil agar bisa membimbing yang sedang mengalami bencana juga dapat disalurkan kepada warga dengan keutamaan agar tidak mengalami trauma yang berlebihan dikala bencana itu akan datang kembali.

Ketiga, pembinaan agama selalu diberikan oleh PP. Persatuan Islam untuk memperluas juga wawasan amil dalam ajaran agamanya, diantara pembinaan tersebut ada kajian di setiap bulannya, pengajian rutin di setiap minggunya dan juga ada kajian jangka panjang yaitu setiap dua bulan sekali (Riniwati, 2016, 151).

\section{Pelatihan}

Untuk menguatkan kompetisi dan kapasitas amil zakat serta mencegah lembaga amil zakat dari kejahatan Money Laundry, sekolah Amil Indonesia mengadakan Pelatiahn Amil Ahli APU PPT (Anti Pencurian Uang dan Pencegahan Pendanaan Terorisme). Pelatihan ini adalah satu masukan kepada amil zakat agar lebih mengetahui tata cara penerimaan dan pemberian dana zakat, infaq dan shadaqah secara tepat dan terarah sesuai denga syariat Islam sehingga menurut Sekjen Forum Zakat, Nana Sudiana, bahwa pelatiahn ini sangatlah penting bagi amil zakat karena dapat mengantisipasi kedepannya terkait kejahatan pencurian uang dan pendanaan terorisme yang bisa saja dialami oleh lembaga zakat. Pelatihan dalam suatu pekerjaan maupun dalam kehidupansehari-hari sangatlah penting dibutuhkan. Para tenaga kerja sangatlah dituntut untuk lebih bisa dalam berbagai macam keahlian serta kompetensi dalam bidang pekerjaannya (Harsuko, 2016: 167).

Dari pelatihan itulah akan timbul rasa tanggung jawab yang lebih terhadap pendayagunaan dana zakat, infaq dan shadaqah yang seharusnya di selurkan sebagaimana mestinya, dan tidak adanya kejadian yang tisak diinginkan oleh 
Usep Saepul Alam, D, Yuliani.

lembaga zakat, salian itu materi Anti pencurian uang dan pencegaan pendanaan terorisme juga merupakan bagian penting bagi pimpinan LAZ yang akan mengikuti sertifikasiamil ahli oleh forum zakat, karena merupakan salah satu kompetisi yang dimiliki ileh amil ahli bagi sebagian lembaga zakat di indonesia.

Pelatihan bagi amil itu sangat penting dilaksanakan, agar dengan pelatihan itu seluruh amil zakat pusat zakat umat bisa lebih meningkatkan kembali wawasan dalam pengelolan dan pendayagunaan dana zakat, infaq dan shadaqah serta fidyah, oleh karena dengan adanya pelatihan yang sesuai dengan kriterian yang sudah ditentukan maka akan bertambah pula kemampuan dalam bekerja amil zakat. tekanan yang sangta kompetitif, menuntut setiap orang harus melakukan yang terbaik bagi seluruh pekerjaan dengan cemerlang keterampilan yang bagus sehingga dapat dilihat oleh atasannya dengan memungkinkan akan lebih mudah untuk naik jabatan (Chaerudin, 2019: 67).

Proses dalam pelaksanaan pelatihan yang dilakukan PP Persis meliputi beberapa susunan acara yang telah diselenggarakan dalam waktu yang telah ditetapkan, diantaranya: Kesatu, pembukaan Kedua, pembacaan Ayat Suci AlQur'an, Ketiga, membacaan Indonesia Raya Kempat,Sambutan-Sambutan dari pihak petinggi lembaga zakat Kelima, materi inti dari acara pelatihan Keenam, Edukasi dari materi pelatihan Ketujuh, penutup dan Mushofahah.

Dari pelatihan yang sudah diselenggarakan oleh pihak PP. Persis kepada para amil zakat yaitu untuk memberikan stimulus yang lebih kuat dalam pendayagunaan dana zakat, infaq dan shadaqah. Oleh karena itu pelatihan ini wajib diikuti oleh semua amil zakat yang sudah bergabung dalam kepengurusan lembaga pusat zakat umat, gunanya untuk lebih memahami bagaimana tata cara pendayagunaan yang baik dan benar, sehingga dapat memenuhi capaian target yang telah ditentukan dalam kurun waktu beberapa tahun kedepan dengan memaksimal SDM yang sudah ada dalam bagian kepengurusan lembaga pusat zakat umat. Dengan adanya pelatihan yang dilakukan oleh PP. Persis diharapakan dapat bermanfaat dan bisa direalisasikan dalam setiap pekerjaan yang akan menjadi tunjangan pekerjaan di lembaga amil zakat.

Dari semua yang dilakukan dalam pelatihan dan pembinaan Pusat Zakat Umat melakukan monitoring terhadap beberapa program binaan yang diberikan kepada desa yang mendjadi pilihan bagi pembentukan dan keberhasilan program Pusat Zakat Umat untuk kedepannya.

Pusat Zakat Umat melaksanakan monitoring program bina desa dan prgram mesjid bangkit satu domba datu santri. Program bina desa ini di lakukan di desa Awi Puncak untuk madrasah Al-Ma'ruf PPI 176 Pasir Jambu, juga pusat zakat umat telah membangun bangunan madrasah 3 bangunan kelas untuk pembangunan pertama dan 4 bangunan kelas 2 tingkat untuk pembangaunan kedua, selian pemberian fasilitas pendidikan nerupa pembinaan bagi para guru, serta penyerahan bantuan paket alat tulis untuk siswa yang bersekolah di 
madrasah tersebut.

Selasa (8/8/2017) untuk program mesjid satu domba datu santri, pusat zakat umat sudah menjalankan program ini pada tahun 2008 dengan sepasang domba yang beranak pinak hingga 30 ekor dalam kurun waktu 3 tahun, dan ada tahun 2016 dengan 4 domba 1 domba jantan dan 3 domba betina, dan pada tahun 2017 dengan 4 domba dengan keseluruhan jumlah 2 domba jantan dan 6 domba betina, yang sudah beranak pinang 4 ekor dari 2 domba dan 2 domba betina sedang hamil untuk saat ini. Penerima manfaat yang disalurkan oleh lembaga pusat zakat umat melalui program umat shaleh sebesar 7.764 penerima manfaat baik itu dari luar negeri maupun dari dalam negeri.

Selain itu juga Pusat Zakat Umat memberikan bantuan dana beasiswa kepada santri yang berprestasi dan unggul dalam bidang keagamaan serta bidang yang lainnya dalam memberikan kontribusi kepada bangsa terhadap prestasi yang telah diraih oleh setiap santri atau santriah. Sabtu (22/6/2019) Pusat Zakat Umat dan BPRS Amanah Rabbaniah sinergis dalam program Umat Pintar yang merupakan salah satu program 5 umat PZU. Sinergis program Umat Pintar ini berupa beasiswa untuk santri berprestasi. Penyerahan beasiswa ini untuk santri yang memag betul berprestasi, kali ini diserahkan kepada santri dan santriawati Pesantren Persatuan Islam 03 pameungpeuk, yang sekaligus berlangsungnya dengan acara pembagian Mukafraah para santri.

Beasiswa ini diserahkan kepada 30 santri berprestasi dari mulai jenjang Tsanawiyah, yang langsung diserahkan oleh perwakilan BPRS Amanah Rabbaniah yang didampingi langsung oleh Direktur Pendayagunaan PZU Heri Sholehudin.

\section{Evaluasi pengelolaan Zakat Pusat Zakat Umat Sumur Bandung}

Menurut bapak Angga Nugraha evaluasi yang dilakukan di lembaga zakat pusat zakat umat dilakukan biasanya pada tiap bulan sekali dengan menentukan dana yang sudah didapatkan sesuai dengan targetnya, Sebelum membahas evaluasi ada baiknya dikaji terlebih dahulu tentang baiaman kinerja yang dilakukan oleh karyawan kepada perusahaan, sehingga ketika melakukan evaluasi dapat maksimal dan merubah seluruh elemen yang menjadi sudut pandang kekurangan. Ada juga evaluasi jangka menengah yaitu pada 3 bulan sekali serta jangka panjang pada satu tahun sekali. Sehingga ditemukanlah hasil dari penghimpunan pada tiap tahunnya yang sudah melebih target yang sudah ditentukan, diantaranya:

Perolehan pada tahu 2015 menghimpun dana sebesar 12,114,898,592 sehingga kurangnya dana yang dihimpun pada tahu 2015 mah mengakibatkan kurangnya pendsitribusian yang disalurkan, maka pada pengelolaannya di perbaiki dan diperluas antara kerjasam dengan perusahaan yang lain, sehingga pada tahun beringkutnya 2016 menghimpun dana lebih besar lagi yakni 
Usep Saepul Alam, D, Yuliani.

32,759,489,055 dengan adanya peningkatan yang menjadi pendistribusian dapat di maksimal dengan baik pada tahun berikutnya lebih di tingkatkan 2017 sebesar $41,383,888,353$ pada tahun ke tahun mengalami peningkatan yang sangat signifikan sehingga pada tahu 2018 lebih melesat dalam dana penghimpunan zakat, infaq dan shadaqah sampai mencapai angka 52.793.844.134,26 dalam pencapain itu maka dapat dilihat dalam pengelolaan zakat bisa dibilang lebih meningkat tahun ke tahunnya, sehingg tidak dapat dipungkiri pada tahun selanjutnya akan lebih meningkat kembali dana zakat, infaq dan shadaqah yang dihimpun dai para donatur yang selalu setia menyumbangkan sebagian hartanya untuk disalurkan melalui lembaga pusat zakat umat.

Evaluasi yang dilakukan oleh lembaga pusat zakat umat yaitu setiap seminggu sekali dengan langsung dipimpin oleh manajer eksekutif untuk melihat kinerja yang sudah dilakukan dalam seminggu dengan tujuan agar dalam menjadi amil tidak sembarang mudah dengan amanah yang diberikan oleh masyarakat amil zakat manapun, oleh karena itu manajer eksekutif menegaskan kepada para amilnya agar bekerja sesuai porsinya dan tidak melakukan hal-hal yang memang diluar dari kinerja masing-masing, kecuali ada permintaan dari amil yang ingin lebih memahami kinerja dari tugas yang lain. Proses Evaluasi yang dilakukan oleh lembaga atau perusahaan merupakan suatu tindakan yang baik untuk memberikan perubahan kepeda seluruh karyawan dalam proses pekerjaan sedang berlangsung. (Budihardjo, 2015: 06).

Dari keseluruhan evaluasi yang dilakukan oleh lembaga pusat zakat umat bisa dihitung hampir tiap bulan dilakukan evaluasi baik evaluasi dana yang himpun maupun evaluasi SDM dalam kinerja disetiap harinya melalui pemantauan yang dilakukan oleh pendamping manajer eksekutif, guna agar dalam pendayagunaan dana zakat, infaq dan shadaqah lebih baik dan dapat menambah penghimpunan disetiap tahunnya untuk didistribusikan kepada masyarakat yang membutuhkan dalam sandang dan pangannya.

Dalam analisis yang sudah dibahas dapat disingkronkan dengan teori George John Terry yaitu tentang konsep manajemen yang dibagi menjadi 4 diantaranya pertama, perencanaan (Planning) yaitu sebagai dasar pemikiran dari tujuan dan penyusunan langkah-langkah yang akan dipakai untuk mencapai tujuan. Merencanakan berarti mempersiapkan segala kebutuhan, memperhitungkan matang-matang apa saja yang menjadi kendala, dan merumuskan bentuk yang bermaksud untuk mencapai tujuan. Kedua, pengorganisasian (Organization) yaitu sebagai cara untuk mengumpulkan orangorang dan menempatkan mereka menurut kemampuan dan keahliannya dallam pekerjaan yang sudah direncanankan. Ketiga, perggerakan (Actuating) yaitu untuk menggerakkan organisasi agar berjalan sesuai dengan pembagian kerja masingmasing serta menggerakan seluruh sumber daya yang ada dalam organisasi agar pekerjaan atau kegiatan yang dilakukan bisa berjalan sesuai dengan rencana dan 
mencapai tujuan. Keempat, pengawasan (Controlling) yaitu untuk mengawasi apakah gerakan dari organisasi ini sudah sesuai dengan rencana atau belum. Serta mengawasi penggunaan sumber daya dalam organisasi agar bisa terpakai secara efektif dan efesien tanpa ada yang ada melenceng dari rencana.

Secara teori bahwa konsep manajemen dapat dilihat dengan seksama bahwa dalam perencanaan harusnya adanya kesepakatan yang sudah pasti dalam menentukan tujuan utama agar mempunyai arahan yang jelas terhadap sumber daya manusia untuk kedepannya, oleh karena itu dengan teori yang penulis singkronkan dengan kenyataan yang ada dilapangan, maka penulis menganalisis tentang bagaimana cara rekrutmen yang dilakukan oleh lembaga pusat zakat umat dengan sumber dari tujuan manajemen menurut Sri Larasati di dalam bukunya yaitu manajemen sumber daya manusia diantaranya: (a) Apa tujuannya diatur? Tujuannya agar lebih terarah dengan jelas alur dari penjalanan proses keberlangsungan untuk hasil yang maksimal sesuai dengan target yang sudah di tentukan. (b) Apa yang diatur? Yang diatur adalah sumber daya manusianya dengan arahan dan penjelasan yang baik sesuai dengan ketentuannya masingmasing dalam melakukan kinerja, serta perencanaan yang matang dan terarah. (c) Mengapa harus diatur? Karena mempunyai tujuan dan target tertentu dalam melakukan perencanaan. (d) Siapa yang mengatur? Yang mengatur adalah sumber daya manusia yang ada di lembaga pusat zakat umat diantaranya ada manager utama, manager eksekutif, kepala cabang dan yang lainnya. (e) Bagaimana mengatur?

Mengaturnya dengan memberikan pemahaman kepada para bawahannya dengan prosedur dan ketentuan yang sudah ada, sehingga SDM yang ada dapat memberikan kinerja yang baik kepada lembaga serta dapat sampai kepada target yang sudah dari awal persetujuan.

Dengan adanya pengaturan, maka tujuan yang telah ditentukan akan terarah dengan baik dan memudahkan kepada para bawahan dalam bekerja sesuai dengan kinerjanya masin-masing, oleh karena itu orang yang mengatur jalannya pekerjaan diharuskan yang sudah berpengalaman dibidangnya agar dalam perngarahan yang ditunjukkan kepada bawahannya sesuai dengan prosedur yang sudah ada dalam undang-undang dan buku panduan yang ada di lembaga pusat zakat umat. Berdasarkan teori yang diungkapkan bahwa dalam melakukan evaluasi terhadap karyawan manajemen harus melihat dulu apakah kinerjanya baik dalam kesehariannya atau sebaliknya.

Upaya kegiatan ini didasari dengan adanya ketidakpahaman masyarakat terhadap pengelolaan zakat yang ada di lembaga pusat zakat umat dengan mempresentasikan program yang sudah menjadi tujuan lembaga PZU, lembaga berharap dengan adanya pelatihan kepada masyarakat, mereka mengetahui bahwa lembaga pusat zakat umat mengelola dana zakat, infaq dan shadaqah dengan mendistribusikan tidak hanya didalam negeri tetapi bisa sampai ke luar 
Usep Saepul Alam, D, Yuliani.

negeri, diantaranya Palestina, Suriah, dan Negara lainnya. Bantuan diberikan berupa materi maupun berupa barang yang sedang dibutuhkan oleh masyarakat tersebut.

Oleh karena itu, pelatihan ini sangat diperlukan untuk menarik minat masyarakat agar dapat menyumbangkan sebagian hartanya kepada masyarakat kurang mampu melalui lembaga Pusat Zakat Umat, pelatihan ini juga diadakan untuk memberikan juga kepada Amil Zakat yang ada dilembaga PZU dalam rangka menguatkan pemahaman bagaimana pendayagunaan dana zakat, infaq dan shadaqah dengan baik dan benar, agar dalam penghimpunan dan pendistribusian itu dirasakan oleh para muzzaki dan mustahiknya yang menerima perolehan dan distribusi yang dilakukan oleh lembaga Pusat Zakat Umat.

\section{PENUTUP}

Hasil dari penelitian yang dilakukan di lembaga Amil Zakat Nasional Pusat Zakat Umat yang beralamat di Jl. Perintis Kemerdekaan, Sumur Bandung Kota Bandung, maka dapat diambil kesimpulan sebagai berikut: (1) Startegi dalam pola recriutment SDM yang dilakukan oleh lembaga Pusat Zakat Umat yaitu dengan adanya tahapan-tahapan yang sudah menjadi bagian dari rencana awal, yaitu pertama adanya relawan yang ditugaskan membantu keseluruhan dalam program PZU. dengan adanya relawan tersebut dapat dilihat sejauh mana skill dan kemampuan dalam pendayagunaan dana zakat, infaq dan shadaqah sehingga dapat ditarik dan ditempatkan sebagaimana kemampuan yang sudah dilakukan dengan adanya ketentuan yang telah ditentukan oleh lembaga Pusat Zakat Umat dan mengetahui pekerjaan yang seharusnya dilakukan. (2) Pembinaan yang diberikan kepada SDM pengelolaan zakat melalui beberapa tahap yatiu adanya kajian-kajian ilmu yang diadakan oleh PP Persis, adanya motivasi berupa arahan yang sesuai dengan kinerjanya masing-masing, adanya wisata religi yang dilakukan setiap satu tahun sekali, guna untuk memberikan semangat kembali dalam bekerja pendayagunaan zakat, infaq dan shadaqah. Setelah adanya pembinaan pelatihan pun sering dilakukan yang salah satunya pelatihan anti pencurian dan pencegahan pendanaan terorisme. (3) Evaluasi juga sudah sangat sering dilakukan oleh lembaga Pusat Zakat Umat diantaranya setiap 2 minggu 1 kali, satu bulan 1 kali, 3 bulan 1 kali dan juga 1 tahun 1 kali yang mendapatkan hasil dari penghimpunan dapat menghasilkan peningkatakan yang sangat baik dan signifikan. 


\section{DAFTAR PUSTAKA}

Amymie, F. (2017) Optimalisasi Pendistribusian dan Pendayagunaan Dana Zakat

Dalam Pelaksanaan Tujuan Program Pembangunan Berkelanjuan, dalam Anida: (Aktualisasi Nuansa Ilmu Dakwah), 17(1), 1-18.

Barthos, D. B. (2012). Manajemen Sumber Daya Manusia. Jakarta: Bumi Aksara.

Chaerudin, A. (2019) Manajemen Pendidikan Dan Pelatihan SDM. Sukabumi: CV Jejak

Elbadiansyah (2019). Manajemen Sumber Daya Manusia. Malang: CV IRDH

Harsuko, (2016) Manajemen Sumber Daya Manusia. Malang: CV Budiatama

Handoko, T. H. (2012). Manajemen Sumberdaya Manusia dan Personalia, Yogyakarta:

Hasibuan, S.P. (2011). Manajemen Dasar, Pengertian dan Masalah, Jakarta: Bumi Aksara.

Indonesia, U.-U. R. (2011). Tentang Pengelolaan Zakat. Kota Cimahi.

Irawan \& Swastha \& Basu, (1997). Manajemen Pemasaran Modern. Cetakan Kelima.

Yogyakarta: Liberty.

Safitri, E (2019). Pengelolaan Mesjid Berbasis Kampus Dalam Meningkatkan Pemberdayaan Masyarakat Tadbir: Jurnal Manajemen Dakwah, 10(10): 20-20.

Saihudin, (2019). Manajemen Sumber Daya Manusia. Ponorogo: Uwais Inspirasi Indonesia.

Setiawan, H. (2017), Manajemen Komunikasi Dompet Ummat Islam Pemberdayaan perekonomian Ummat Islam dalam Ilmu Dakwah: Academic Journal for Homiletic Studies, 11(1), 2548-8708.

Sri, L M. (2018). Manajemen Sumber Daya Manusia. Yogyakarta: Budi Utama.

Yani, D. A. (2011). Manajemen Sumber Daya Manusia. Bandung: Humaniora. 
Usep Saepul Alam, D, Yuliani. 